\title{
IMPLEMENTASI METODE QUALITY FUNCTION DEPLOYMENT (QFD) UNTUK PERBAIKAN PROSES PEMBELAJARAN DI FAKULTAS EKONOMI UNIVERSITAS ISLAM INDONESIA
}

\author{
Oleh: \\ Siti Nursyamsiah * \\ Tenti Isti'adah ")
}

\section{ABSTRAKSI}

Penelitian ini menguji bagaimana kualitas pembelajaran yang sudah ditawarkan direspon oleh mahasiswanya. Atribut yang digunakan untuk mengukur kepuasan mahasiswa terhadap proses pembelajaran adalah Kernampuan Dosen, Metode Pembelajaran, Kurikulum, Sarana Perpustakaan, Teknologi Informasi dan Fasilitas Penunjang Pembelajatan lainnya. Dengan menggunakan alat analisis QFD didapatkan hasil bahwva belum semua atribut proses pembelajaran sesuai dengan yang diharapkan mahasiswa. Hampir semua atribut proses pembelajaran perlu diperbaiki, dengan urutan prioritas sebagai berikut: ketersediann dan penggunaan pustaka, sarana penunjang, penggunaan teknologi informasi, kemampuan dosen, kurikulum, dan metode pembelajaran.

\section{A. PENDAHULUAN}

Memasuki abad 21 persaingan antar lembaga pendidikan tinggi semakin ketat. Apalagi pemerintah telah mengeluarkan kebijakan deregulasi pendidikan yang mengijinkan pihak asing untuk mendirikan perguruan tinggi baru di Indonesia. Dengan adanya deregulasi ini, maka persaingan antar perguruan tinggi, baik PTN maupun PTS akan semakin meningkat. Lembaga pendidikan tinggi yang ingin berkembang harus berkompetisi dan harus mampu menyediakan jasa yang berkualitas serta memusatkan perhatiannya pada kepuasan pelanggan, dan ini merupakan strategi pilihan bagi perguruan tinggi yang ingin membedakan diri mereka dari kompetitornya.

Para pelanggan sekarang ini lebih menuntut dalam hal kualitas jasa yang mèreka harapkan dari lembaga jasa. Penelitian yang dilakukan oleh Bennet ( $1990,1992)$ menunjukkan bahwa pelanggan akan berpaling jika ada alternatif

-) Siti Nursyamsiah adalah Dosen Fakultas Ekonomi Universitas Islam Indonesia

*) Tenti Isti'adah adalah Alumni Fakultas Ekonomi Universitas Islam Indonesia 
Siti Nursyamsiah dan Tenti Isti'Adah: Implementasi Metode Quality Function Deployment ...

yang lebih baik yang tersedia pada lembaga jasa lain. Mereka lebih suka lembaga jasa yang membebankan harga yang lebih tinggi tetapi menyediakan layanan yang unggul dibandingkan dengan harga yang lebih rendah tetapi dengan pelayanan yang lebih buruk. Tuntutan-tuntutan pelanggah yang semakin meningkat akan kualitas jasa tersebut mengharuskan pihak manajemen/ pimpinan dan karyawan (dosen \& karyawan administrasi) memiliki komitmen terhadap pengembangan kualitas layanan yang diberikan oleh organisasi mereka.

Keberhasilan suatu perguruan tinggi tidak hanya dilihat dari satu faktor saja, tetapi banyak faktor yang menentukan keberhasilan tersebut. Baik faktor internal maupun faktor eksternal. Faktor internal meliputi: jumlah dan kualitas dosen yang memadai, mahasiswa sebagai motor penggerak, pelayanan yang memadai dan memuaskan, sarana dan fasilitas yang mendukung dan lain-lain. Sedangkan faktor eksternal adalah hubungan perguruan tinggi dengan masyarakat, pemerintah dan perguruan tinggi lainnya.

Berdasarkan faktor internal dan eksternal dituntut agar perguruan tinggi memiliki strategi agar tetap survive. Strategi tersebut adalah strategi internal yaitu mengoptimalkan sesuatu yang bersifat operasional dalam perguruan tinggi, seperti proses belajar mengajar, mengatur jadwal ruangan, jadwal ujian, yang kesemuanya merupakan tugas dari bagian pengajaran, strategi eksternal yaitu strategi agar perguruan tinggi diminati oleh masyarakat, perusahaan dan pemerintah seperti mengadakan seminar, loka karya, pelatihan dosen dan mahasiswa, mengikuti karya ilmiah penelitian yang dapat memberikan hasil, menyekolahkan dosen-dosen agar memiliki jenjang yang lebih tinggi sehingga ilmu yang didapat bertambah luas.

Untuk menghadapi semua tantangan ini serta kesadaran akan pentingnya kualitas pada tingkat global yang dipicu oleh keberhasilan penerapan Total Quality Management (TQM) di perusahaan-perusahaan Jepang. Maka banyak perusahaan yang mengadopsi strategi TQM. TQM menurut (Ishikawa Dalam Pawitra, 1993:135), diartikan sebagai perpaduan semua fungsi manajemen, semua bagian dari suatu perusahaan dan semua orang ke dalam falsafah holistik yang dibangun berdasarkan konsep kualitas, teamwork, produktifitas dan kepuasan pelanggan. Untuk mencapai kualitas pada perguruan tinggi yang diharapkan, maka Perguruan Tinggi seharusnya mengadopsi penerapan TQM.

Konsep TQM itu sendiri berfokus pada semua orang atau tenaga kerja, bertujuan untuk terus menerus meningkatkan nilai yang diberikan bagi pelanggan dengan biaya penciptaan nilai yang lebih rendah daripada nilai suatu produk sehingga dengan begitu perusahaan dapat memahami dengan seksama harapan pelanggan.

Untuk memenuhi harapan pelanggan tersebut, maka perlu diadakan riset mengidentifikasi kebutuhan pelanggan dengan menggunakan|konsep Quality Function Deployment (QFD), dengan House Of Quality sebagai modelnya dikembangkan untuk menjamin bahwa produk yang bersangkutan dapat memuaskan kebutuhan para pelanggan dengan jalan membentuk tingkat kualitas yang diperlukan pada pengembangan produk.

House Of Quality merupakan matrik yang menggambarkan keseluruhan informasi yang diperlukan untuk mengembangkan proses pembelajaran. Data yang diperlukan untuk pembuatan House Of Qualityadaiah data dari pelanggan 
(mahasiswa) dan data dari institusi, sedangkan QFD adalah suatu sistem bagi desain barang atau jasa yang mendasarkan atas keinginan konsumen, yang mana sistem desainnya melibatkan partisipasi anggota seluruh fungsi organisasi, QFD menerjemahkan apa yang dibutuhkan pelanggan menjadi apa yang dihasilkan organisasi, atau dengan kata lain QFD juga merupakan praktek menuju perbaikan proses yang dapat memungkinkan organisasi untuk melampaui harapan pelanggannya. Penelitian ini bertujuan untuk mengetahui seberapa besar tingkat kepentingan, tingkat kepuasan, pada masing-masing atribut proses pembelajaran dan mengetahui usaha apa yang dilakukan institusi untuk memenuhi kebutuhan mahasiswa, serta merekomendasikan prioritas-prioritas yang harus dilakukan institusi untuk memenuhi kebutuhan mahasiswa terhadap proses pembelajaran.

\section{B. QUALITY FUNCTION DEPLOYMENT (QFD)}

QFD adalah salah satu alat TQM. Dimana QFD di kembangkan pertama kali di Jepang oleh Mitshubishi's Kobe Shipyard pada tahun 1972. yang kemudian diadopsi oleh Toyota. Ford Motor Company dan Xerox membawa konsep ini ke Amerika serikat pada tahun 1986. Semenjak itu QFD banyak diterapkan oleh perusahaan-perusahaan Jepang, Amerika serikat dan Eropa. Teknik QFD ini tumbuh dari teknik manajemen mutu terpadu, yang kemudian dari istilah QFD tersebut timbul gagasan bahwa mutu berarti menghasilkan kepuasan pelanggan dan tugas pengembangan mutu tersebut adalah menciptakan (menyebarkan) fungsi produk untuk menciptakan produk (David Inwood, 1995).

Uselac mendefinisikan QFD sebagai Suatu praktek untuk mendesain proses-proses dalam suatu perusahaan untuk memberikan tanggapan kepada kebutuhan para konsemennya.

QFD merupakan alat perencanaan produk yang memfokuskan secara khusus pada kebutuhan dan harapan konsumen. Hal ini sering disebut sebagai "Voice of the Customer". QFD merupakan suatu pendekatan sistematik yang menentukan tuntutan atau permintaan konsumen dan menterjemahkan tuntutan konsumen ke dalam desain teknis, pemanufakturan, perencanaan produksi dengan tepat. Konsep Quality Function Deployment (QFD) dikembangkan untuk menjamin bahwa produk yang memasuki tahap produksi benar-benar akan dapat memuaskan kebutuhan konsumen dengan jalan membentuk tingkat kualitas yang diperlukan dan memenuhi kesesuaian maksimum pada setiap pengembangan produk.

Fokus utama QFD adalah melibatkan konsumen pada proses pengembangan produk sedini mungkin. QFD merupakan praktek untuk merancang suatu proses sebagai tanggapan terhadap kebutuhan konsumen. QFD menterjemahkan apa yang dibutuhkan konsumen menjadi produk yang dihasilkan organisasi.

QFD memungkinkan organisasi untuk memprioritaskan kebutuhan konsumen, menemukan tanggapan inovatif terhadap kebutuhan konsumen, dan memperbaiki proses hingga tercapai efektivitas maksimum. QFD juga merupakan 
Siti Nursyamsiah dan Tenti Isti‘Adah: Implementasi Metode Quality Function Deplòyment ...

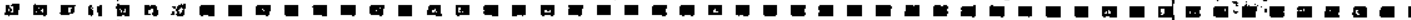

praktek menuju perbaikan proses yang memungkinkan organisasi bisa melampaui harapan konsumen.

C. KOMPONEN DALAM PROSES PEMBELAJARAN

Proses pembelajaran dapat diukür tingkat keberhasilannya dengan menggunakan beberapa komponen, antara lain :

\section{Kemampuan Dosen}

Faktor yang sangat penting dalam menunjang keberhasilan.suatu studi adalah adanya suatu interaksi manusiawi dosen dengan mahasiswa. Karena bantuan dosen kepada mahasiswa didalam dan diluar perkuliahan formal dapat berpengaruh, terutama dorongan yang bersifat psikis untuk penyelesaian tugastugas dan penyelesaian studi. bagi mahasiswa. Dosen pada umumnya merupakan figur yang dapat memberi semangat belajar; keakraban yang bersifat informal dan manusiawi yang dapat merangsang semangat belajar, minimal terhadap mata kuliah dari dosen yang bersangkutan.

Di samping dosen sebagai penyemangat, keberhasilan suatu studi juga ditentukan oleh faktor komunikasi dosen-mahasiswa.dimana komunikasi tersebut terdiri dari komunikasi primer yaitu komunikasi langsung tanpa media/ alat (media massa). Sedangkan komunikasi sekunder yaitu komunikasi yang menggunakan media atau mediated communication. Dengan demikian keberhasilan proses komunikasi tersebut banyak tergantung kepada faktor dosen dan mahasiswa.serta relevansi pesan yang disampaikan dengan cara, alat, atau media yang digunakan. Untuk memperlancar proses belajar maka harus dianalisis faktor dosen dan mahasiswa serta berbagai hambatannya.

Laporan DIRJENDIKTI tentang peningkatan kualitas dosen dan tenaga penunjang akademik dilakukan melalui peningkatan kesempatan melarijutkan pendidikan, seminar, lokakarya dan sebagainya. (Ekroman, 2002), Lindgren, (1976), dalam Nunuk Nur Shokiyah, (2005), menyatakan bahwa perlunya seorang dosen memahami teori belajar karena hal ini penting untuk membantu dosen memperlancar proses pembelajaran dan membantu dosen dalam meningkatkan ketrampilannya sebagai seorang pengajar yang efektif.

\section{Metode Mengajar}

Proses pembelajaran di perguruan tinggi pada umumnya sering menggunakan metode tatap muka atau ceramah, dengan kata lain berpusat pada lembaga atau dosen bukan pada mahasiswa. Di dalam sistem ini mahasiswa tidak (atau sedikit sekali) ikut menentukan dan harus berusaha menyesuaikan cara belajarnya dengan apa yang telah ditentukan baik lembaga maupun dosen. Kemudian hasil belajar mahasiswa untuk mata kuliah yang bersangkutan pada umumnya diukur dengan jalan memberikán ujian tertentu dan mahasiswa tidak perlu tahu bagaimana penilaian tersebut sebenarnya akan dilaksanakan.

Menurut (Trigwell dkk, 1994), dalam Nunuk Nur Shokiyah, (2005), dalam penelitiannya menyatakan bahwa pengajaran yang baik dimaknai sebagai 
pengajaran yang memberikan umpan balik yang bermakna, berusaha memahami kesulitan yang dihadapi oleh mahasiswa, memberikan penjelasan yang baik, membuat materi menjadi menarik, memberi solusi yang terbaik kepada mahasiswa dan menunjukkan minat terhadap apa yang disampaikan oleh mahasiswa. Pendekatan belajar mengajar yang dimaksud adalah pendekatan yang berfokus kepada mahasiswa, juga menambahkan hubungan pengajaran dan belajar membantu program pengembangan dalam rangka meningkatkan pembelajaran mahasiswa.

\section{Kurikulum}

Kurikulum adalah seperangkat pengalaman belajar berupa materi ajaran (mata kuliah) yang tersedia bagi pencapaian program studi jenjang tertentu. Daiam SKS setiap jenjang memiliki seperangkat jumlah SKS sesuai dengan jenjang program yang diselenggarakan.

Penerapan kurikulum itu sendiri merupakan tingkatan sistem pembelajaran yang paling penting dalam metode pembelajaran (learning), dan memerlukan ketetapan dan tindak lanjut pada tiap aspek program yang telah dirancang. Bagian kurikulum ini membutuhkan informasi yang berisi: silabi, rancangan pengajaran mata kuliah, dokumentasi kerja, penilaian laporan, rencana kegiatan, pencatatan hasil, dokumentasi kegagalan dan dokumentasi performansi di bawah rata-rata, selain itu kegiatan yang dilakukan secara benar dicatat dan didokumentasikan, uraian tentang penilaian kemajuan serta kriteria untuk perengkingan dan penilaian hasil merupakan elemen penting dalam sistem pengukuran kualitas. (Sallis, 1993), dalam (Nunuk Nur Shokiyah, 2005).

Desain kurikulum meliputi dokumentasi maksud dan tujuan tiap program. Selanjutnya membuat bentuk silabi atau dokumen mata kuliah untuk keperluan validasi isi, kelengkapan yang perlu dimasukkan berupa data-data yang dibutuhkan oleh program dan sumber-sumber data lain yang tersedia. Datadata dari pengajar dan pendukung proses pembelajaran merupakan input untuk membentuk rancangan sistem kualitas.

Pelaksanaan kurikulum dan manajemen program membutuhkan spesifikasi yang berisi rancangan team work. Aturan-aturan berkaitan dengan team, tanggung jawab dan tingkat wewenang dapat diuraikan. Laporan berkaitan dengan penguji dari luar (extemal examiners), Moderator dan Verifiers akan memberikan data-data penting bagi pengemb angan kualitas pembelajaran.

\section{Teknologi Informasi}

Semakin canggihnya teknologi yang ada maka sudah tentu perguruan tinggi juga saat ini banyak yang menggunakan teknologi, karena dengan menggunakan teknologi perguruan tinggi akan dengan cepat memperoleh informasi yang ingin diserapnya dan juga sangat membantu dalam menyelesaikan pekerjaan dengan cepat.

Schcter, (1999), dalam Nunuk Nur Shokiyah, (2005), menurut hasil studinya menyatakan siswa yang menggunakan instruksi berbasis komputer prestasinya lebih baik daripada yang tidak, di tambahkan siswa yang belajar dengan waktu yang lebih sedikit ketika mereka menerima intruksi melalui komputer. 
Siti Nursyamsiah dan Tenti Isti“Adah: Implementasi Metode Quality Function Deployment ...

Dari beberapa pendapat di atas dapat disimpulkan bahwa penggunaan teknologi informasi sangat membantu mahasiswa dalam belaja dan juga dalam menyerap informasi yang ada, dan siswa yang belajar dengan berbasis pada komputer prestasinya lebih baik dari pada yang tidak, tetapi hal ini juga harus dipertimbangkan banyaknya biaya yang dikeluarkan untuk pembelian komputer dan jaringan internet, serta biaya penggunaan jasa internet, pengadaan pelatihan karena tidak semua mahasiswa telah menguasai perkembangan teknologi informasi.

\section{Fasilitas}

Dengan adanya fasilitas yang memadai yang disediakan oleh perguruan tinggi maka mahasiswa akan merasa betah dan nyaman untuk berlama-lama dikampus. Seperti yang disebutkan oleh Siahay, (2002), dalam Nunuk Nur Shokiyah, (2005), fasilitas terdiri dari fasilitas akademik yang berupa perpustakaan, ruang kuliah, alat penunjang kuliah, aula, ruang seminar, ruang sidang, dan fasilitas non akademis berupa lapangan parkir, olahraga, fasilitas keagamaan dan fasilitas himpunan.

\section{Hasil Penelitian Terdahulu}

Penelitian mengenai peningkatan kualitas pelayanan pendidikan dilakukan Siahay, (2002) dalam Nunuk Nur Shokiyah, (2005), di institut pendidikan tinggi di tanggerang dengan menggunakan metode QFD dimana hasilnya adalah elemen karakteristik kualitas yang potensial untuk dikembangkan adalah program kerjasama dan program laboratorium. Wignjosoebroto, (1999). dalam Nunuk Nur Shokiyah, (2005), meneliti di institut teknologi sepuluh November (ITS) tentang peningkatan proses pembelajaran dengan menggunakan metode QFD dan Analytical Hierarchy Process (AHP) dimana hasilnya adalah tugas akhir mempunyai pengaruh sangat besar dalam pencapaian tujuan belajar.

Sahney \& Karunes,2004, meneliti di department management studies Indian Institute of Technologi, di New Delhi Indian, tentang perspektif mahasiswa terhadap kualitas institusi dengan menggunakan metode QFD dan SERVQUAL. dimana hasilnya bahwa desain karakteristik yang didefinisikan melalui QFD adalah sebagai berikut Visi dan Misi yang dinyatakan dengan baik, desain kurikulum yang didefinisikan dengan baik, perencanaan dan desain kurikulum dan dievaluasi secara periodik.

Penelitian mengenai proses pembelajaran oleh (Vermunt, 1994) dalam (Nunuk Nur Shokiyah, 2005), yaitu tentang pengajaran konstruktif di dalam perguruan tinggi, dan bagaimana pembelajaran menggunakan ketrampilan belajar untuk membangun pengetahuan mereka sendiri secara independent dan konstruktif oleh Vermunt disebut sebagai gaya belajar. Bagaimana gaya belajar berkaitan dengan indikator kesuksesan belajar yaitu rata-rata skor ujian, presentasi ujian yang dilalui dan kecepatan belajar.

Banyak ahli yang meneliti tentang keterkaitan antara cara dosen mengajar dan cara mahasiswa belajar. (Trigwell, 1999) dalam (Nunuk Nur Shokiyah, 2005), meneliti hubungan antara pendekatan dosen mengajar dengan pendekatan mahasiswa dalam belajar. Hasil studi menyebutkan bahwa membantu program pengembangan dalam rangka meningkatkan pembelajäran siswa. Persepsi 
mahasiswa tentang dosen yang bagus berkorelasi dengan pendekatan yang mendalam dalam belajar.

Penelitian mengenai penggunaan teknologi informasi dalam dunia pendidikan dilakukan oleh (Wilson, 2003) dalam (Nunuk Nur Shokiyah, 2005) Hasilnya bahwa proses belajar elektronik secara potensial meningkatkan kesempatan belajar. (Schater, 1999) dalam (Nunuk Nur Shokiyah, 2005), meneliti tentang pengaruh teknologi pendidikan dalam proses belajar, hasil studi menyatakan bahwa kelas yang menggunakan pengajaran berbasis teknologi informasi prestasinya lebih tinggi dibandingkan dengan yang tidak menggunakan teknologi informasi.

\section{METODOLOGI PENELITIAN}

\section{Populasi dan Sampel}

Populasi adalah ruang lingkup atau besaran karaktristik dari seluruh objek yang diteliti. Untuk dipelajari dan kemudian ditarik kesimpulannya. Populasi dalam penelitian ini adalah Mahasiswa fakultas ekonomi Ull Yogyakarta, dan dosen fakultas ekonomi U!I Yogyakarta. Objek yang akan diikut sertakan dalam penelitian ini adalah mahasiswa semester lima (5) keatas, dan dosen fakultas ekonomi UII Yogyakarta sebagai respon teknisnya.

Sampel adalah sebagian populasi yang dikarakteristikan dan hendak diselidiki dan dapat mewakili keseluruhan populasi. Dalam penelitian ini penulis mengambil subyek sampel sebanyak 30 orang responden dari mahasiswa fakultas ekonomi UII yogyakarta, 30 orang responden dari dosen fakultas ekonomi Ull yogyakarta. Menurut Roscoe (1975) dalam buku (Uma sekaran 2006, hal:160) mengusulkan aturan untuk menentukan ukuran sampel, dimana ukuran sampel lebih dari 30 dan kurang dari 500 adalah tepat untuk kebanyakan peneliti, dimana sampel dipecah kedalam subsampel: (pria/wanita, junior/senior, dan sebagainya), ukuran sampel minimum 30 orang untuk tiap kategori adalah tepat, sedangkan desain pengambilan sampel ini menggunakan teknik non probability sampling yaitu teknik pengambilan sampel yang tidak memberi peluang atau kesempatan sama bagi setiap unsur atau anggota populasi untuk dipilih menjadi sampel.

\section{Variabel Penelitian dan Pengukuran Variabel}

Variabel yang digunakan dalam penelitian ini adalah atribut proses pembelajaran seperti:

1. Kemampuan dosen adalah faktor yang sangat penting dalam menunjang keberhasilan suatu studi serta adanya suatu interaksi manusiawi antara dosen dengan mahasiswa sangat dibutuhkan, dengan adanya bantuan dosen kepada mahasiswa baik didalam maupun diluar perkuliahan formal dapat berpengaruh terutama dorongan yang bersifat psikis untuk menyelesaikan tugas-tugas dan menyelesaikan studi.

2. Metode pembelajaran adalah proses pembelajaran perguruan tinggi yang pada umumnya sering digunakan adalah metode tatap muka atau ceramah, dengan kata lain berpusat pada lembaga atau dosen bukan mahasiswa. 
Siti Nursyamsiah dan Tenti Isti'Adah: Implementasi Metode Quality Function Deployment ...

3. Penerapan kurikulum adalah tingkatan sistem pembelajaran yang paling penting dalam metode pembelajaran, memerlukan ketetapan dan tindak lanjut pada tiap áspek program yang dirancang.

4. Ketersediaan dan penggunaan pustaka adalah penilaian mahasiswa terhadap fasilitas fisik yang disediakan oleh fakuitas ekónomi UII.

5. Teknologi informasi adalah teknologi yang digunakan untuk memperoleh informasi dengan cepat dan sangat membantu mahasiswa dalam mengakses sumber-sumber pembelajaran.

6. Sarana dan prasarana adalah sebagai alat pendukung dan penggerak agar proses belajar dapat berjalan lancar, efektif dan efesien.

Dari keenam variabel tersebut diatas, diukur melalui 39 item pertanyaan yang menggambarkan bahwa suatu kegiatan dalam proses pembelajaran mahasiswa dirancang secara sistematis agar para mahasiswa dapat belajar dengan efektif dan memahami materi yang diajarkan. Item-item tersebut diukur dengan menggunakan skala likert 5 point pada setiap item pertanyaan, yaitu responden diminta untuk menentukan tingkat kepentingan dan tingkat kepuasan mahasiswa dalam proses pembelajaran dengan memilih point yang ada pada setiap pertanyaan, dimana point 1 adalah sangat tidak penting/sangat tidak puas, nilai dua (2) adalah tidak penting/tidak puas, nilai tiga (3) adalah cukup penting/cukup puas, nilai empat (4) adalah penting/puas, nilai lima (5) adalah sangat penting/sangat puas, kemudian diolah dengan program SPSS untuk mendapatkan angka rata-rata tingkat kepentingan dan tingkat|kepuasan..

Sedangkan respon teknis adalah tanggapan dari institusi untuk memenuhi kebutuhan mahasiswa dengan cara memberikan pelayanan berupa atribut proses pembelajaran yang diinginkan oleh mahasiswa melalui respon teknis yang disediakan oleh institusi. Respon teknis diukur dengan menggunakan skala likert 5 point, yaitu dengan cara menyebarkan kuesioner kepada dosen yang terdiri dari 39 item pertanyaan yang sama seperti kuesioner yang disebarkan kepada mahasiswa, dimana point 1 adalah sangat tidak baik/bagus, point 2 adalah tidak baik/bagus, point 3 adalah cukup baik/bagus, point 4 adalah baik/bagus, point 5 adalah sangat baik/bagus,

\section{E. ANALISIS DAN PEMBAHASAN}

\section{Statistik Deskriptif Voice of Customerterhadap Atribut Proses Pembelajaran}

Dalam proses pembelajaran atribut berikut ini merupakan faktor yang sangat penting dalam menunjang keberhasilan suatu studi. Hasil penilaian mahasiswa tentang proses pembelajaran di fakultas ekonomi Uli, nilai rata-rata kepuasan yang paling tinggi ditunjukkan oleh atribut tersedianya teknologi informasi dengan nilai rata-rata 4,02, kemudian diikuti oleh atribut Kurikulum $(3,7)$, Metode Pembelajaran $(3,48)$ dan Kemampuan Dosen $(3,41)$. Sedangkan tingkat kepuasan sedang ditunjukkkan pada atribut Fasilitas lainnya $(3,3)$ dan Ketersediaan dan Penggunaan sarana Perpustakaan $(3,28)$. 
Tabel 1

Hasil Penilaian Mahasiswa pada Atribut Metode Pembelajaran

\begin{tabular}{|c|l|c|l|c|l|}
\hline \multirow{2}{*}{ No } & \multirow{2}{*}{ Atribut } & \multicolumn{2}{c|}{ Kepuasan } & \multicolumn{2}{c|}{ Kepentingan . } \\
\cline { 3 - 7 } & & Rata-rata & \multicolumn{1}{c|}{ Kategori } & Rata-rata & Kategori \\
\hline 1 & Kemampuan Dosen & 3.41 & Tinggi & 4.22 & Sangat Tinggi \\
\hline 2 & Metode Pembelajaran & 3.48 & Tinggi & 4.04 & Sangat Tinggi \\
\hline 3 & Kurikulum & 3.70 & Tinggi & 4.36 & Sangat Tinggi \\
\hline 4 & $\begin{array}{l}\text { Ketersediaan dan Penggunaan } \\
\text { Sarana Perpustakaan }\end{array}$ & 3.28 & Sedang & 4.21 & Sangat Tinggi \\
\hline 5 & Teknologi Informasi & 4.02 & Sangat Tinggi & 3.16 & Sedang \\
\hline 6 & Fasilitas lainnya & 3.30 & Sedang & 4.30 & Sangat Tinggi \\
\hline Rerata Total & 3,53 & Tinggi & 4,04 & Sangat Tinggi \\
\hline
\end{tabular}

Sumber : Hasil pengolahan data primer

Walaupun kepuasan mahasiswa terhadap metode pembelajaran sudah terpenuhi atau berhasil, namun secara relatif masih dibawah kepentingan atau harapan mahasiswa, hal ini wajar karena kepentingan atau harapan bersifat ideal sehingga selalu melebihi kepuasan atau kinerja yang bersifat realita.

\section{Statistik Deskriptif Respon Teknis Terhadap Atribut Proses Pembelajaran}

\section{Pembentukan Respon Teknis}

Pihak fakultas ekonomi Ull yogyakarta melakukan pengelolaan respon teknis untuk memenuhi berbagai atribut proses pembelajaran yang digunakan mahasiswa tersebut melalui beberapa kegiatan yang dapat dikelompokkan menjadi Kemampuan dosen, metode pembelajaran, kurikulum, ketersediaan dan penggunaan pustaka, fasilitas, sarana dan prasarana. Berbagai bentuk ini dapat ditihat pada tabel respon teknis di bawah ini.

Tabel 2

Respon Teknis Fakultas Ekonomi UII

\begin{tabular}{|c|l|c|}
\hline Atribut & & SKOR \\
\hline 1 & Kemampuan Dosen & 2.72 \\
\hline 2 & Metode Pembelajaran & 2,70 \\
\hline 3 & Kurikulum & 3,47 \\
\hline 4 & Ketersediaan dan Penggunaan Sarana Perpustakaan & 3,39 \\
\hline 5 & Teknologi Informasi & 3,13 \\
\hline 6 & Fasilitas lainnya & 3,99 \\
\hline & Rerata total & 3,23 \\
\hline
\end{tabular}

Sumber: Hasil pengolahan data primer 
Siti Nursyamsiah dan Tenti Isti'Adah: Implementasi Metode Quality Function Deployment ...

Hasil penilaian respon teknis pada atribut proses pembelajaran menunjukkan bahwa, skor tertinggi yang diperoleh pada atribut fasilitas pembelajaran $(3,99)$, kemudian atribut Kurikülum $(3,47)$, Ketersediaan dan Penggunaan Sarana Perpustakaan $(3,39)$. Sedangkan atribut lainnya menunjukkan skor dengan kategori sedang yakni atribut Teknologi informasi $(3,13)$, Kemampuan Dosen $(2,72)$ dan atribut Metode Pembelajaran $(2,70)$.

\section{Korelasi Antar Atribut dalam Respon Teknis}

Kekuatan hubungan-hubüngan antar atribut respon teknis ditentukan melalui pengujian korelasi, atribut yang memiliki koefesien korelasi tinggi menunjukan hubungannya kuat, sebaliknya yang memiliki koefesien korelasi rendah berarti lemah. Tabel berikut menunjukkan besar koefesien korelasi antar atribut respon teknis.

Berdasarkan klasifikasi rendah - sedang - tinggi tersebut, maka nilai korelasi antar dimensi respon teknik dalam tabel 3 dapat digunakan untuk membuat matrik hubungan antar respon teknik, antar dimensi yang memiliki hubungan kuat diberi simbol $*$; yang memiliki hubungan sedang diberi simbol $\square$ dan yang hubungànnya lemah diberi simbol 0 , seperti terlihat pada gambar 1 di bawah ini.

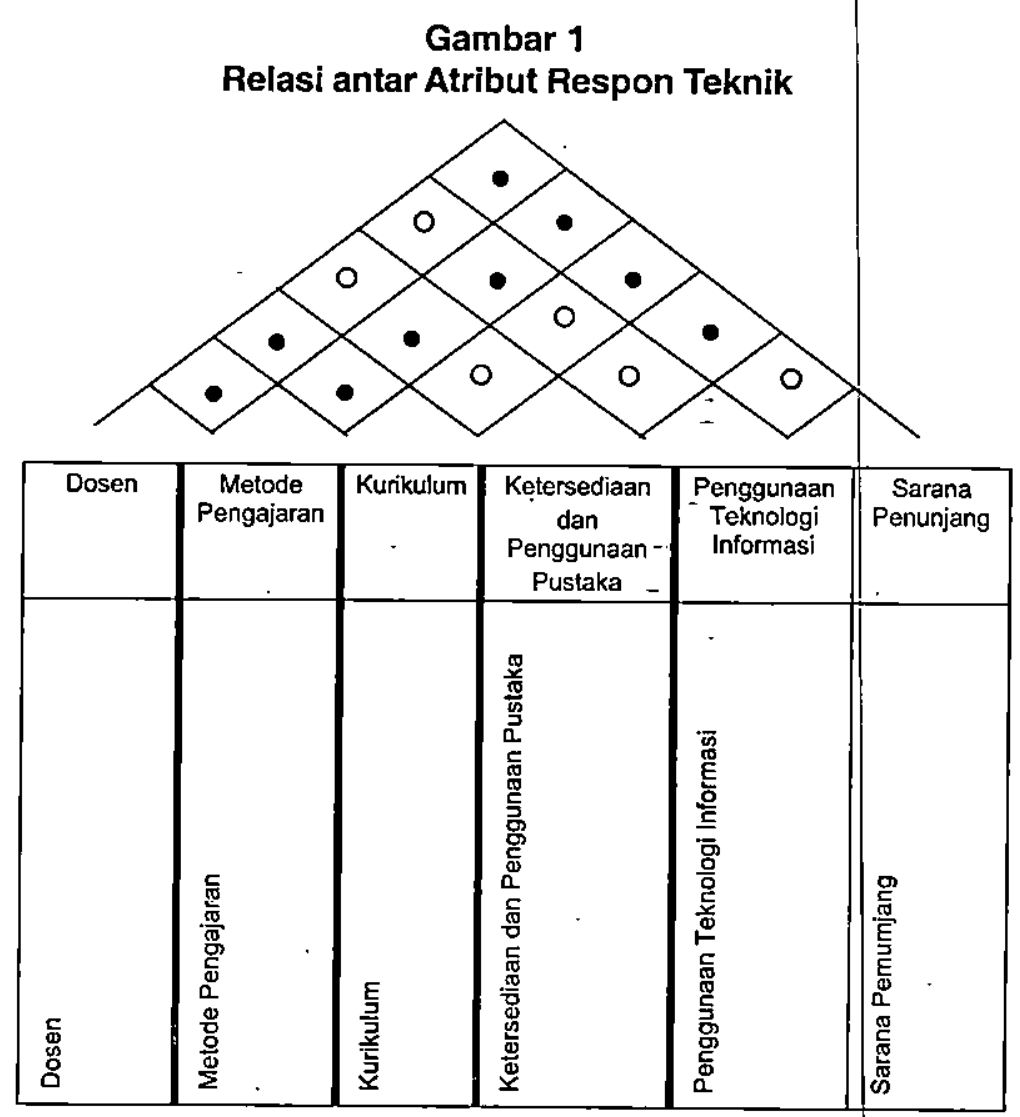

Sumber: Pengolahan data primer 
Hasil korelasi antar atribut respon teknis dilihat dari atribut kemempuan dosen menunjukkan bahwa adanya hubungan lemah antara kemempuan dosen dengan ketersediaan penggunaan pustaka, dan Kemempuan dosen dengan penggunaan teknologi informasi, artinya kemampuan dosen dalam atribut proses pembelajaran dengan menggunakan teknologi informasi masih lemah terutama dalam hal komunikasi dengan mahasiswa lewat sarana e-mail, dan dosen menanggapi pertanyaan mahasiswa lewat $e$-mail, hal ini disebabkan karena mahasiswa itu merasa susah apabila proses pembelajaran menggunakan sarana e-mail, komunikasi antara dosen dan mahasiswa tidak lancar, serta ketrampilan memecahkan masalah kurang berkembang. Sedangkan atribut proses pembelajaran seperti metode pembelajaran, kurikulum, sarana dan prasarana menunjukkan hubungan sedang, artinya atribut proses pembelajaran yang diberikan oleh fakultas ekonomi UIl sudah mewakili tingkat kepentingan dan kepuasan yang diharapkan, namun bukan berarti tidak diperlukan lagi perbaikan dalam proses pembelajaran. Dari hasil tersebut justru akan memicu agar atribut proses pembelajaran harus lebih ditingkatkan lagi sehingga menunjukkan hubungan yang kuat diantara korelasi respon teknis.

Tabel 3

Korelasi Antar Atribut Respon Teknis

\begin{tabular}{|c|c|c|c|c|c|c|}
\hline Atribut & Dosen & $\begin{array}{c}\text { Metode } \\
\text { Pengajaran }\end{array}$ & Kurikulum & $\begin{array}{c}\text { Ketersediaan } \\
\text { dan } \\
\text { Penggunaan } \\
\text { Pustaka }\end{array}$ & $\begin{array}{l}\text { Penggunaan } \\
\text { Teknologi } \\
\text { Informasi }\end{array}$ & $\begin{array}{c}\text { Sarana } \\
\text { Penunjang }\end{array}$ \\
\hline Dosen & & $\begin{array}{r}0,505 \\
\text { Sedang }\end{array}$ & $\begin{array}{r}0,613 \\
\text { Sedang }\end{array}$ & $\begin{array}{r}0,199 \\
\text { Lemah } \\
\end{array}$ & $\begin{array}{r}0,151 \\
\text { Lemah }\end{array}$ & $\begin{array}{r}0,480 \\
\text { Sedang } \\
\end{array}$ \\
\hline $\begin{array}{l}\text { Metode } \\
\text { Pengajaran }\end{array}$ & $\begin{array}{l}0.505 \\
\text { Sedang }\end{array}$ & & $\begin{array}{r}0,595 \\
\text { Sedang }\end{array}$ & $\begin{array}{r}0,455 \\
\text { Sedang }\end{array}$ & $\begin{array}{r}0,482 \\
\text { Sedang }\end{array}$ & $\begin{array}{r}0,547 \\
\text { Sedang }\end{array}$ \\
\hline $\begin{array}{c}\text { Kurikulum } \\
-\end{array}$ & $\begin{array}{l}0,613^{-} \\
\text {Sedang }\end{array}$ & $\begin{array}{r}0,595 \\
\text { Sedang }\end{array}$ & : & $\begin{array}{r}0,230 \\
\text { Lemah }\end{array}$ & $\begin{array}{r}0,099 \\
-\quad \text { Lemah }\end{array}$ & $\begin{array}{r}0,653 \\
\text { Sedang }\end{array}$ \\
\hline $\begin{array}{l}\text { Ketersediaan } \\
\text { dan } \\
\text { Penggunaan } \\
\text { Pustaka }\end{array}$ & $\begin{array}{l}0,199 \\
\text { Lemah }\end{array}$ & $\begin{array}{r}0,455 \\
\text { Sedang }\end{array}$ & $\begin{array}{r}0,230 \\
\text { Lemah }\end{array}$ & - & $\begin{array}{r}0,120 \\
\text { Lemah }\end{array}$ & $\begin{array}{r}0,461 \\
\text { Sedang }\end{array}$ \\
\hline $\begin{array}{l}\text { Penggunaan } \\
\text { Teknologi } \\
\text { Informasi }\end{array}$ & $\begin{array}{l}0,151 \\
\text { Lemah }\end{array}$ & $\begin{array}{r}0,482 \\
\text { Sedang }\end{array}$ & $\begin{array}{r}0,099 \\
\text { Lemah }\end{array}$ & $\begin{array}{r}0,120 \\
\text { Lemah }\end{array}$ & & $\begin{array}{l}-0,211 \\
\text { Lemah }\end{array}$ \\
\hline $\begin{array}{l}\text { Sarana } \\
\text { Penunjang }\end{array}$ & $\begin{array}{l}0,480 \\
\text { Sedang }\end{array}$ & $\begin{array}{r}0,547 \\
\text { Sedang }\end{array}$ & $\begin{array}{r}0,653 \\
\text { Sedang }\end{array}$ & $\begin{array}{r}0,461 \\
\text { Sedang }\end{array}$ & $\begin{array}{r}-0,211 \\
\text { Lemah }\end{array}$ & \\
\hline
\end{tabular}

Sumber : Hasil pengolahan data primer

Korelasi antar respon teknis dilihat dari metode pembelajaran, semuanya menunjukkan hubungan sedang, artinya semua atribut yang diberikan oleh fakultas ekonomi Ull belum memenuhi harapan yang diinginkan, sehingga dalam hal ini harus lebih ditingkatkan lagi agar atribut proses pembelajaran kedepannya memiliki hubungan yang kuat antara korelasi respon teknis. 
Siti Nursyamsiah dan Tenti Isti'Adah: Implementasi Metode Quality Function Deployment ...

Korelasi antar respon teknis dilihat dari kurikulum menunjukkan bahwa adanya hubungan lemah antar respon teknis yaitu kurikulum dengan ketersediaan penggunaan pustaka, dan kurikulum dengan penggunaan teknologi informasi, artinya pihak fakultas belum bisa/mampu memenuhi kebutuhan atau keinginan yang diharapkan. Sedangkan atribut proses pembelajaran seperti dosen, metode pembelajaran, sarana dan prasarana memiliki hubungan sedang.

Korelasi antar respon teknis dilihat dari ketersediaan dan penggunaan pustaka memiliki hubungan yang lemah antara dosen, kurikulum, penggunaan teknologi informasi. Sedangkan yang lainnya seperti: metode pembelajaran dan sarana penunjang memiliki hubungan sedang antar respon teknis.

Korelasi antar respon teknis dilihat dari penggunaan teknologi informasi memiliki hubungan yang lemah antara dosen, kurikulum, ketersediaan dan penggunaan pustaka, sarana dan prasarana, sedangkan yang lainnya seperti metode pembelajaran memiliki hubungan yang sedang.

Korelasi antar respon teknis dilihat dari sarana dan prasarana memiliki hubungan sedang antara dosen, metode pembelajaran, kurikulum, ketersediaan dan penggunaan pustaka, sedangkan atribut proses pembelajaran sarana penunjang penggunaan teknologi informasi memiliki hubungan sedang antar respon teknis.

\section{Relasi Atribut Voice Of Customer dengan Respon Teknik}

Kekuatan relasi antara atribut voice of customer dengan respon teknik ditentukan bersama oleh peneliti dengan pihak perusahaan (fakultas ekonomi UIi), hasil penentuan kekuatan relasi tersebut ditunjukan dalam tabel di bawah..

Hasil penilaian relasi antara atribut voice of customerdengan respon teknis menunjukkan bahwa adanya hubungan sedang antara kurikulum dengan dosen, sedangkan atribut yang lainnya menunjukkan hubungan yang lemah antara voice of customerdengan respon teknis, hubungan lemah menunjukkan bahwa pihak fakultas ekonomi belum mampu memenuhi kebutuhan atau keinginan yang sesuai dengan harapan pelanggan (mahasiswa), sehingga diperlukan perbaikan secara khusus agar dapat memenuhi kebutuhan dan harapan pelanggan tersebut terutama dalam hal: sarana penunjang, ketersediaan dan penggunaan pustaka, penggunaan teknologi informasi, kemempuan dosen, metode pembelajaran dan terakhir kurikulum 
Tabel 4

Korelasi Voice of Customer dengan Respon Tehnis

\begin{tabular}{|c|c|c|c|c|c|c|}
\hline Rehnis & Dosen & $\begin{array}{c}\text { Metode } \\
\text { Pengajaran }\end{array}$ & Kurikulum & $\begin{array}{c}\text { Ketersediaan } \\
\text { dan } \\
\text { Penggunaan } \\
\text { Pustaka }\end{array}$ & $\begin{array}{l}\text { Penggunaan } \\
\text { Tehnologi } \\
\text { Informasi }\end{array}$ & $\begin{array}{c}\text { Sarana } \\
\text { Penunjang }\end{array}$ \\
\hline Dosen & $\begin{array}{r}0.240 \\
\text { Lemah }\end{array}$ & $\begin{array}{r}0,259 \\
\text { Lemah }\end{array}$ & $\begin{array}{r}0,086 \\
\text { Lemah } \\
\end{array}$ & $\begin{array}{r}0,025 \\
\text { Lemah }\end{array}$ & $\begin{array}{l}-0,157 \\
\text { Lemah }\end{array}$ & $\begin{array}{l}0,208 \\
\text { Lemah } \\
\end{array}$ \\
\hline $\begin{array}{l}\text { Metode } \\
\text { Pengajaran }\end{array}$ & $\begin{array}{r}0.218 \\
\text { Lemah }\end{array}$ & $\begin{array}{r}0.193 \\
\text { Lemah }\end{array}$ & $\begin{array}{r}0.042 \\
\text { Lemah } \\
\end{array}$ & $\begin{array}{r}0.097 \\
\text { Lemah } \\
\end{array}$ & $\begin{array}{r}-0.207 \\
\text { Lemah } \\
\end{array}$ & $\begin{array}{r}0,204 \\
\text { Lemah } \\
\end{array}$ \\
\hline Kurikulum & $\begin{array}{r}0.349 \\
\text { Sedang }\end{array}$ & $\begin{array}{r}0.268 \\
\text { Lemah } \\
\end{array}$ & $\begin{array}{r}0.291 \\
\text { Lemah }\end{array}$ & $\begin{array}{r}0,055 \\
\text { Lemah } \\
\end{array}$ & $\begin{array}{l}-0,178 \\
\text { Lemah }\end{array}$ & $\begin{array}{r}0,255 \\
\text { Lemah }\end{array}$ \\
\hline $\begin{array}{l}\text { Ketersediaan dan } \\
\text { Penggunaan } \\
\text { Pustaka }\end{array}$ & $\begin{array}{r}0.076 \\
\text { Lemah }\end{array}$ & $\begin{array}{r}0.114 \\
\text { Lemah }\end{array}$ & $\begin{array}{r}-0.024 \\
\text { Lemah }\end{array}$ & $\begin{array}{r}-0.110 \\
- \text { Lemah }\end{array}$ & $\begin{array}{r}-0,316 \\
\text { Lemah }\end{array}$ & $\begin{array}{r}0,181 \\
\text { Lemah }\end{array}$ \\
\hline $\begin{array}{l}\text { Penggunaan } \\
\text { Teknologi } \\
\text { Informasi }\end{array}$ & $\begin{array}{r}0.181 \\
\text { Lemah }\end{array}$ & $\begin{array}{r}0.181 \\
\text { Lemah }\end{array}$ & $\begin{array}{r}0.171 \\
\text { Lemah }\end{array}$ & $\begin{array}{l}-0.075 \\
\text { Lemah }\end{array}$ & $\begin{array}{r}-102 \\
\text { Lemah }\end{array}$ & $\begin{array}{r}0,196 \\
\text { Lemah }\end{array}$ \\
\hline $\begin{array}{l}\text { Sarana } \\
\text { Penunjang }\end{array}$ & $\begin{array}{r}0.056 \\
\text { Lemah }\end{array}$ & $\begin{array}{r}0.108 \\
\text { Lemah }\end{array}$ & $\begin{array}{r}-0.054 \\
\text { Lemah }\end{array}$ & $\begin{array}{r}-0.172 \\
\text { Lemah } \\
\end{array}$ & $\begin{array}{r}-0.308 \\
\text { Lemah } \\
\end{array}$ & $\begin{array}{r}-\quad 0,049 \\
-\quad \text { Lemah } \\
\end{array}$ \\
\hline
\end{tabular}

Sumber: Hasil pengolahan data primer

Tabel 5

Relasi antara Atribut Voice of Customer dengan Respon Teknis

\begin{tabular}{|c|c|c|c|c|c|c|}
\hline $\begin{array}{l}\text { Tehnis Respon } \\
\text { Voice Of Customer }\end{array}$ & Dosen & $\begin{array}{c}\text { Metode } \\
\text { Pengajaran }\end{array}$ & Kurikulum & $\begin{array}{l}\text { Ketersediaan } \\
\text { dan } \\
\text { Penggunaan } \\
\text { Pustaka }\end{array}$ & $\begin{array}{l}\text { Penggunaan } \\
\text { Tehnologi } \\
\text { Informasi }\end{array}$ & $\begin{array}{c}\text { Sarana } \\
\text { Penunjang }\end{array}$ \\
\hline Dosen & 0 & 0 & 0 & $\circ$ & 0 & 0 \\
\hline $\begin{array}{l}\text { Metode } \\
\text { Pengajaran }\end{array}$ & 0 & 0 & 0 & 0 & 0 & 0 \\
\hline Kurikulum & - & 0 & 0 & 0 & 0 & 0 \\
\hline $\begin{array}{l}\text { Ketersediaan dan } \\
\text { Penggunaan } \\
\text { Pustaka }\end{array}$ & 0 & 0 & 0 & 0 & 0 & 0 \\
\hline $\begin{array}{l}\text { Penggunaan } \\
\text { Teknologi } \\
\text { Informasi }\end{array}$ & 0 & 0 & o & 0 & $0^{-}$ & 0 \\
\hline $\begin{array}{l}\text { Sarana } \\
\text { Penunjang }\end{array}$ & 0 & 0 & 0 & 0 & 0 & 0 \\
\hline
\end{tabular}

Sumber: hasil pengolahan data primer. 
Siti Nursyamsiah dan Tenti Isti'Adah: Implementasi Metode Quality Function Depilojyment ....

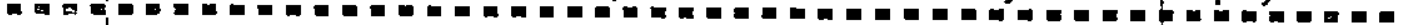

\section{Perhitungan QFD}

Hasil lengkap perhitungan QFD dapat dilihat pada lampiran tabel di bawah menunjukan hasil QFD dalam beintuk yang diperingkas. Dua hasil QFD yang diperlihatkan dalam tabel tersebut, pertama adalah absolete importance dan kedua adalah servquel score.

Absolute importance merupakan tingkat kepentingan absolute yang memuat beberapa skala tingkat kepentingan, sedangkan Servquelmerupakan fungsi gap antara harapan konsumen terhadap layanan dan persepsi mereka terhadap layanan aktual yang dihasilkan perusahaan, harapan konsumen terhadap kualitas layanan merupakan keinginan atau permintaan ideal konsumen terhadap layanan yang akan diberikan oleh penyedia layanan, servquel skor adalah selisih antara nilai rata-rata kepuasan dengan nilai rata-rata kepentingan, seperti yang dihasilkan dalam tabel 6 , nilai negatif menunjukkan bahwa atribut satu dengan yang lainnya tidak saling mendukung atau bertentangan dengan usaha pemenuhan keinginan konsumen, sedangkan nilai positif menunjukkan bahwa antara atribut satu dengan yang lainnya saling mendukung dalam pemenuhan keinginan konsumen.

\section{Hasil Absolute Important}

Bagian absolute importance dalam QFD dapat menjelaskan prioritas perbaikan dari pandangan perusahaan atau respon teknik. Skor terbesar dalam absolute importance menunjukan respon teknis tersebut harus mendapatkan perhatian lebih tinggi dari yang lain.

Terlihat dalam tabel QFD diatas, respon teknis pada sarana penunjang memiliki skor terbesar dan diberi ranking 1. Ranking 1 ini menjelaskan bahwa proses pembelajaran dilihat dari sarana penunjang harus mendapatkan prioritas tinggi untuk diperbaiki oleh fakultas ekonomi yang bertugas dan bertanggung jawab pada divisi tersebut. Perbaikan pada atribut ini akan mempengaruhi kelengkapan sarana pembelajaran dalam ruang kuliah, tersedianya sarana internet bagi mahasiswa, tersedianya ruang dan peralatan bagi dosen untuk mempersiapkan alat bantu proses pembelajaran, tingkat kemudahan mahasiswa terhadap perpustakaan, fasilitas pendukung yang disediakan di perpustakaan, dan tersedianya ruang laboratorium bagi mahasiswa.

Secara berurutan prioritas perbaikan bagi fakultas ekonomi UII adalah sarana penunjang, kurikulum, kemampuan dosen, ketersediaan dan penggunaan pustaka, metode pembelajaran dan penggunaan teknologi informasi. 
Tabel 6

Ringkasan Hasil Perhitungan QFD

\begin{tabular}{|c|c|c|c|c|c|c|c|c|c|}
\hline $\begin{array}{l}\text { Tehnik } \\
\text { Atribut } \\
\text { Proses } \\
\text { pembelajaran }\end{array}$ & 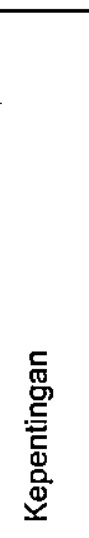 & 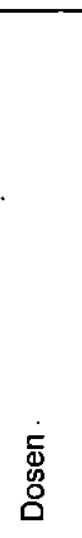 & 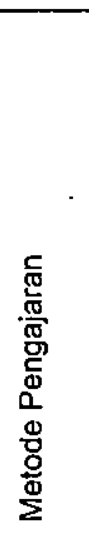 & 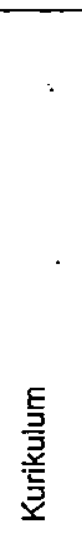 & 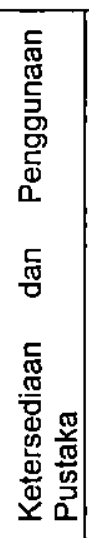 & 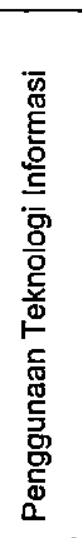 & 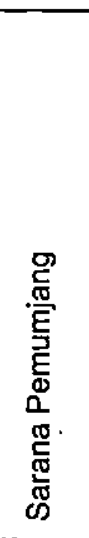 & 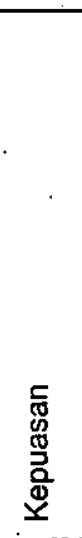 & 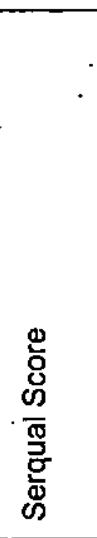 \\
\hline Dosen & 4,22 & & & & & & & 3,41 & $-0,807$ \\
\hline $\begin{array}{l}\text { Metode } \\
\text { Pembelajaran }\end{array}$ & 4,04 & & & & & : & & $3,48^{\circ}$ & $-0,556$ \\
\hline Kurikulum & 4,36 & & & & & & & 3,70 & $-0,656$ \\
\hline $\begin{array}{l}\text { Ketersediaan dan } \\
\text { Penggunaan } \\
\text { Pustaka }\end{array}$ & 4,21 & & & & & & & 3,28 & $-0,928$ \\
\hline $\begin{array}{l}\text { Penggunaan } \\
\text { Teknologi } \\
\text { Informasi }\end{array}$ & 4,02 & & & & & & & 3,16 & $-0,858$ \\
\hline Sarana Penunjang & 4,46 & & & & & & & 3,54 & $-0,919$ \\
\hline $\begin{array}{l}\text { Absolute } \\
\text { Importance }\end{array}$ & & 4,22 & 4,04 & 4,36 & 4,21 & 4,02 & 4,46 & & - - \\
\hline $\begin{array}{l}\text { Relative } \\
\text { Importance of } \\
\text { Product Atributes }\end{array}$ & & 3 & 5 & 2 & 4 & 6 & 1. & & $-\cdot$ \\
\hline
\end{tabular}

Sumber: hasil pengolahan data primer

Pada gambar absolute importance respon teknis, sarana penunjang dan kurikulum jauh lebih tinggi dibandingkan respon teknis lainnya. Tingginya perbedaan ini menjelaskan ketimpangan keberhasilan antara kedua respon teknis tersebut dengan respon teknis penggunaan teknologi informasi. Semakin besar skor yang ada maka menunjukan bahwa proses pembelajaran pada dimensi sarana penunjang dan kurikulum belum baik, atau pihak fakultas ekonomi belum bisa memenuhi respon teknis tersebut. 


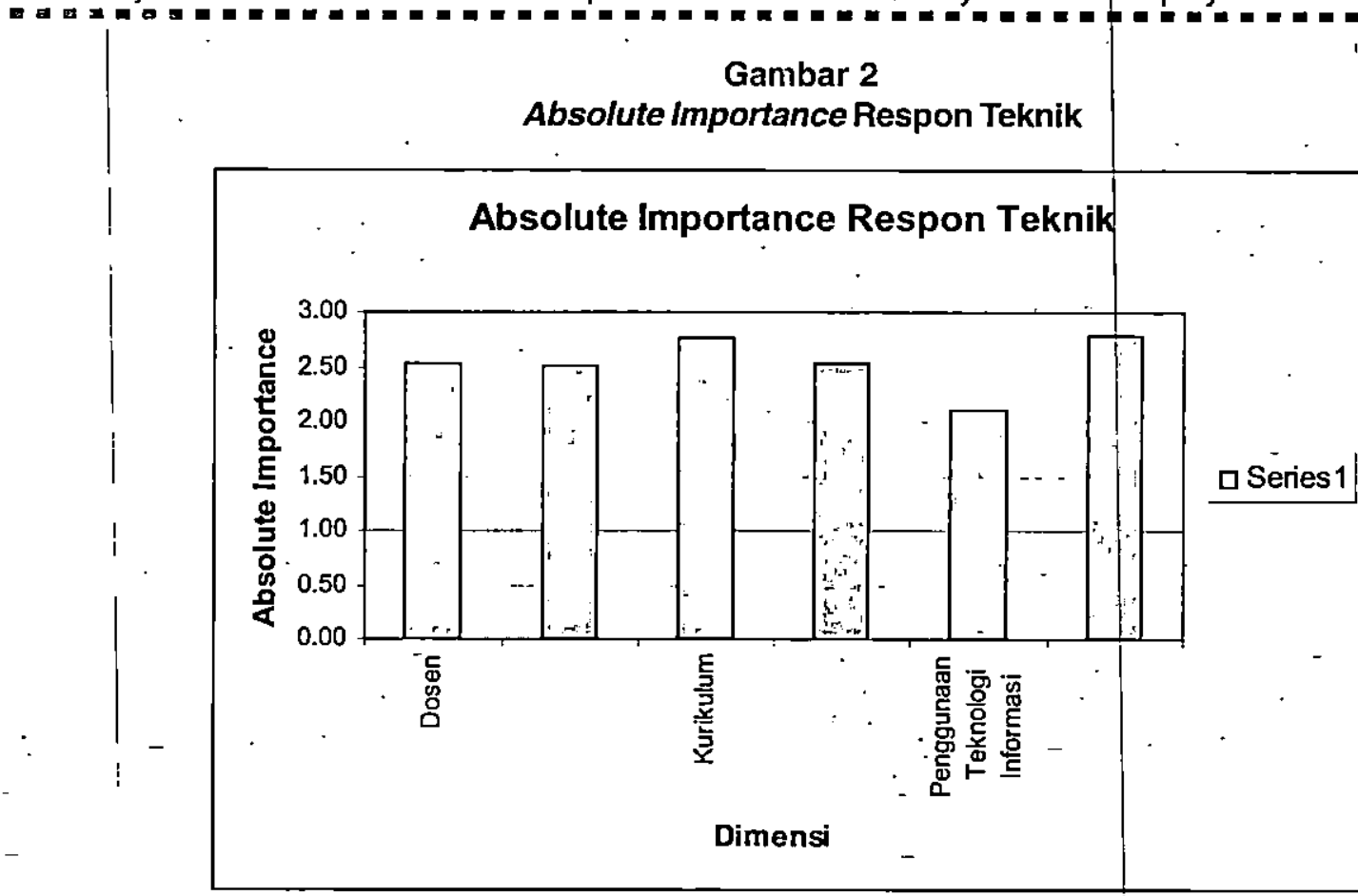

Sumber: Pengolahan data primer

\section{Hasil Servquel}

Nilai dalam servque/merupakan selisih antara kinerja dengan kepentingan, hasil negatif menjelaskan performance perusahaan (fakultas ekonomi UII) lebih rendah dari kepentingan mahasiswa pada atribut yang bersangkutan, atau berarti proses pembelajaran dalam atribut tersebut masih belum bagus.

Pada tabel tersebut terlihat bahwa, proses pembelajaran dilihat dari ketersediaan dan penggunaan pustaka memiliki nilai negatif paling besar, berarti pelaksanaan proses pembelajaran ini paling jauh tertinggal dibandingkan dengan proses pembelajaran dilihat dari atribut metode pembelajaran. Atribut dalam metode pembelajaran meliputi: sistem penyampaian perkuliahan dengan metode ceramah, kuliah diselingi diskusi kelompok tentang materi yang diajarkan, mahasiswa diberi kesempatan bertanya atau mèngklarifikasikan materi pembelajaran, metode pembelajaran bersifat teaching to leaming agar perkuliahan bersifat student centered dan learning oriented, ketrampilan memecahkan masalah dapat berkembang, dosen member contoh-contoh konkrit, bagi kelas yang besar (100 mahasiswa lebih) dilaksanakan kelas paralel, dosen menugaskan mahasiswa untuk mengerjakan PR; tugas PR dikembalikan kepada mahasiswa. Secara berurutan atribut proses pembelajaran negatif terbesar selanjutnya adalah sarana penunjang, penggunaan teknologi informasi, dosen, kurikulum, dan metode pembelajaran. 
Gambar 3

Nilai Servqual Score pada Atribut Proses Pembelajaran

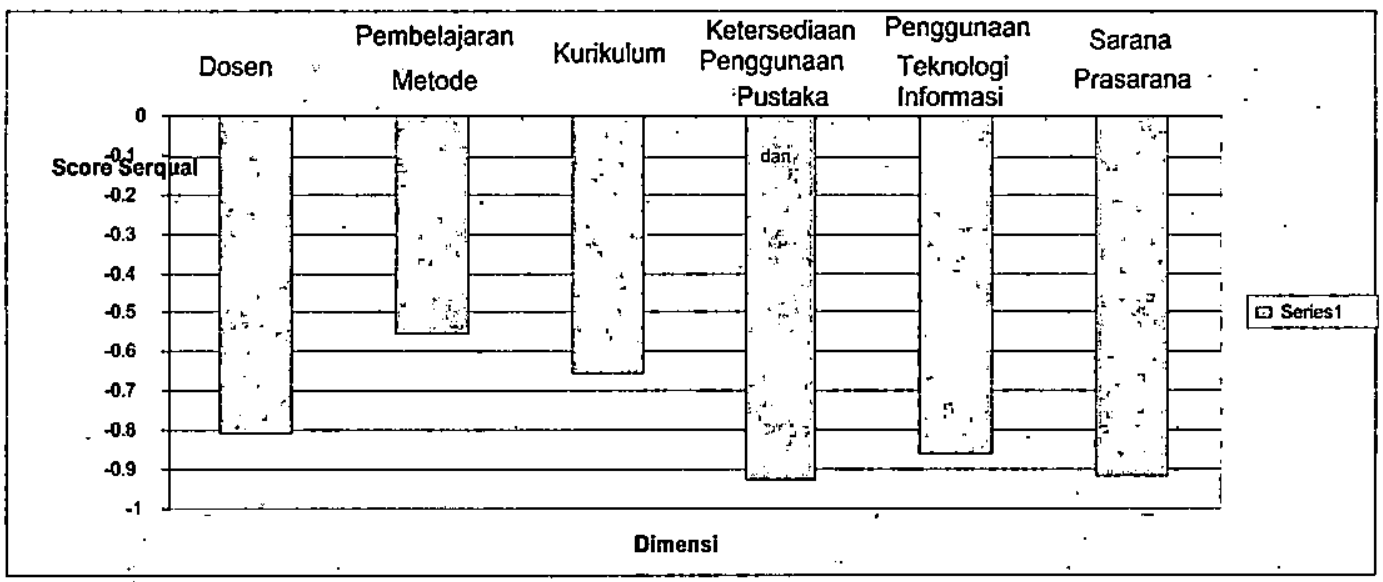

Sumber: Pengolahan data primer

Hasil servqualnegatif ini bukan berarti kinerja proses pembelajaran fakultas ekonomi UII tidak baik, karena dalam uraian diskritif di atas telah ditunjukan bahwa, penilaian mahasiswa terhadap kepuasan dan kepentingan proses pembelajaran di fakultas ekonomi UII sudah dalam kategori tinggi / sangat tinggi. kepentingan juga bersifat ideal, sehingga akan selalu dinilai lebih tinggi meskipun kepuasan sudah mengalami perbaikan yang banyak. Dalam kedudukan seperti ini maka nilai negatif pada servquallebih merupakan prioritas perbaikan berdasarkan kepentingan mahasiswa.

Dari hasil servquel score diatas, atribut proses pembelajaran paling utama diprioritaskan untuk diperbaiki agar kedepannya menjadi lebih baik adalah atribut yang memiliki nilai negatif terbesar diantara yang lainnya yaitu ketersediaan dan penggunaan pustaka, sarana penunjang, penggunaan teknologi informasi, kemampuan dosen, kurikulum, dan terakhir metode pembelajara 
Siti Nursyamsiah dan Tenti Isti'Adah: Implementasi Metode Quality Function Deplöyment ....

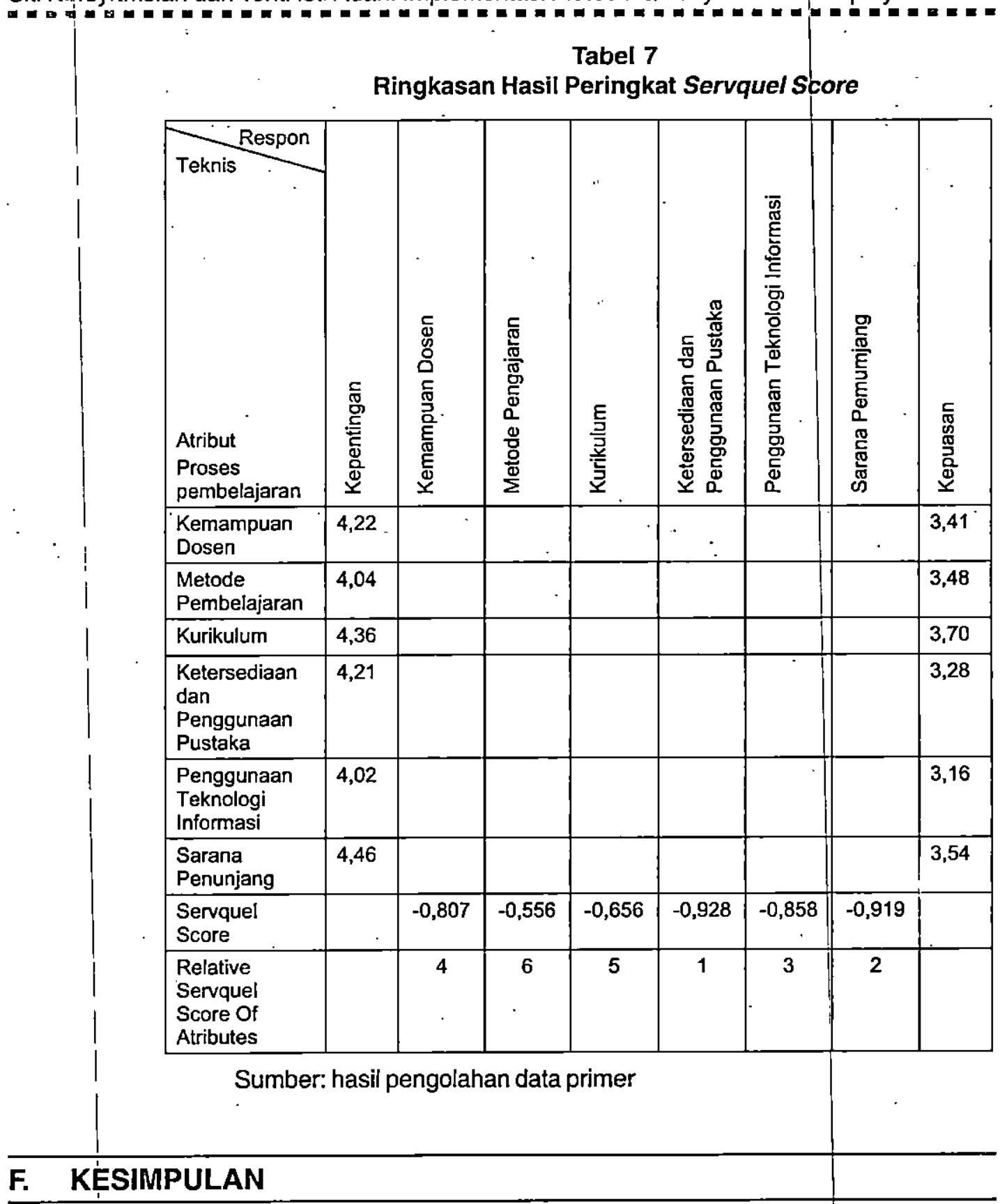

Berdasarkan hasil penelitian seperti yang telah diuraikan pada bab sebelumnya, dapat ditarik kesimpulan sebagai berikut:

Berdasarkan Penilaian mahasiswa terhadap proses pembelajaran di fakultas ekonomi UII dilihat dari:

1. Dari hasil pengujian statistik diskriptif, penilaian mahasiswa terhadap kemampuan dosen dilihat dari tingkat kepuasan berada dalam kategori 
tinggi dengan nilai rata-rata $(3,7.7)$, sedangkan kemampuan dosen dilihat dari tingkat kepentingan berada dalam kategori sangat tinggi dengan nilai rata-rata $(4,50)$. Hal ini menunjukkan bahwa rata-rata mahasiswa merasa puas dan merasa sangat penting dengan kemampuan dosen yang diberikan oleh fakultas ekonomi UII, walaupun kepuasan dan kepentingan terhadap dosen sudah terpenuhi atau berhasil, namun bukan berarti tidak diperiukan lagi perbaikan kualitas proses pembelajaran di fakultas ekonomi UII.

2. Dari hasil pengujian statistik diskriptif, penilaian mahasiswa terhadap proses pembelajaran dilihat dari tingkat kepuasan berada dalam kategori tinggi dengan nilai rata-rata $(3,93)$, sedangkan metode pembelajaran dilihat dari tingkat kepentingan berada dalam kategori sangat tinggi dengan nilai rata-rata $(4,47)$, hal ini menunjukkan rata-rata mahasiswa merasa puas dan sangat penting dengan metode pembelajaran yang diberikan oleh fakultas ekonomi UI.

3. Dari hasil pengujian statistik diskriptif, penilaiaan mahasiswa tentang kurikulum dilihat dari tingkat kepuasan berada dalam kategori tinggi dengan nilai rata-rata $(3,83)$, sedangkan kurikulum dilihat dari tingkat kepentingan berada dala kategori sangat tinggi dengan nilai rata-rata $(4,37)$.

4. Dari hasil pengujian statistik diskriptif, penilaian mahasiswa terhadap ketersediaan dan penggunaan pustaka dilihat dari tingkat kepuasan adalah sedang dengan nilai rata-rata $(3,03)$, sedangkan ketersediaan penggunaan pustaka dilihat dari tingkat kepentingan berada dalam kategori sangat tinggi dengan nilai rata-rata $(4,30)$, hal ini wajar karena kepentingan atau harapan bersifat ideal sehingga selalu melebihi kepuasan kinerja yang bersifat realita.

5. Dari hasil pengujian statistik diskriptif, penilaian mahasiswa terhadap teknologi informasi dilihat dari tingkat kepuasan berada dalam kategori tinggi dengan nilai rata-rata $(4,33)$, sedangkan teknologi informasi dilihat dari tingkat kepentingan berada dalam kategori sedang dengan nilai ratarata $(2,97)$, karena mahasiswa merasa susah apabila proses pembelajaran dengan menggunakan sarana e-mail, sehingga komunikasi menjadi tidak lancar, serta ketrampilan memecahkan masalah tidak berkembang.

6. Dari hasil pengujian statistik diskriptif, penilaian mahasiswa terhadap sarana dan prasarana dilifiat dari tingkat kepuasan dan tingkat kepentingan rata-rata mahasiswa merasa puas dan penting dengan sarana dan prasarana yang disediakan oleh fakultas ekonomi UII. Kepuasan berada dalam kategori tinggi dengan nilai rata-rata $(3,83)$, sedangkan sarana dan prasarana dilihat dari tingkat kepentingan berada dalam kategori sangat tinggi dengan nilai rata-rata $(4,70)$.

7. Prioritas yang harus dilakukan oleh fakultas ekonomi UII dilihat dari hasil servquel score yang memiliki nilai negatif terbesar adalah meningkatkan dan memperbaiki proses pembelajaran secara berurutan yaitu dimulai dari ketersediaan dan penggunaan pustaka, sarana penunjang, penggunaan teknologi informasi, kemampuan dosen, kurikulum, dan terakhir metode pembelajaran. 
Siti Nursyamsiah dan Tenti Isti'Adah: Implementasi Metode Quality Function Deployment ...

\begin{tabular}{c|c|c|}
\hline & DAFTAR PUSTAKA & \\
\hline & $\cdot$ \\
\hline
\end{tabular}

Agitha indri, (2007). " Penerapan Pengembangan Fungsi Kualitas Untuk Desain Pelayanan Jasa Pendidikan di Jurusan Manajemen UII Berdasarkan Harapan Pelanggan", Jurusan ekonomi manajemen, Universitas Islam Indonesia.

Bennet, A. (1990), "Many Consumers Expect Better Senvice and Say The Willing to Pay for It". Waal Street Journal, November, 12.

Bennet, R. (1992), "Gaining a Competitive Advantage Through Customer Satifaction" Bank Marketing 24 (12).

Nunuk, Nur Shokiyah. (2005). "Persepsi Mahasiswa TerhadapProses Pembelajaran Dengan Menggunakan Quality Of Deployment" (Studi Kasus Pada Fakultas Psikologi Universitas Muhamadiyah Surakarta), Tesiș Megister Jürusan Manajemen (Tidak dipublikasikan, Yogyakarta: Program Pasca Sarjana UGM).

Purnama, Nursya'bani. (2006). Manajemen Kuạilitas Perspektif Global. Edisi Pertama. Yogyakarta: Ekonisia.

Puspitarini, Dian. (2006). "Aplikasi Metode Quality Function Deployment Dalam Perencanaan Kualitas Produk Pada PT. Panganmas Inti Persada Cilacap". Jurusan Ekonomi Manajemen, Universitas Islam Indonesia.

Rohayati, Suprihatini. (2005). "Aplikasi Quality Function Deployment (QFD) Di Industri Teh Hitam Orthodox Indonesia", Jurnal Pengkajian Dan Pengembangan Teknologi Pertanian, Vol. 8, No. 3, (November), 426435.

Sangeeta Sahney \& S Karunes,(2004), A Serqual and QFD approach to total Quality Education, A student perspective, Intemational Joumal of Productivity and Performance Management, Vol 53:2. Emeral Group Publishing Limited

Sekaran, Uma. (2006). "Reseach Methods For Business". Edisi 4. Jakatra:Salemba Empat.

Tjiptono, F. dan Diana, A, (2002), "Total Quality Management", Yogyakarta: Andi Offset. 